\title{
The Role of Indonesian Women for Conflict Resolution on Qur'anic Interpretation
}

\author{
Ahmad Atabik \\ Institut Agama Islam Negeri Kudus \\ atabik78@gmail.com
}

\section{ABSTRAK}

Artikel ini mengkaji tentang penyelesaian konflik berbasis gender dalam perspektif al-Qur'an dan implementasinya oleh kaum perempuan Indonesia dalam upaya resolusi konflik. Menggunakan studi dokumentasi, riset ini menunjukkan bahwa konflik dalam al-Qur'an memuat konflik berbasis gender di dalamnya. Nilai al-Qur'an dalam resolusi konflik yaitu; tabayun; tahkim; al-Syura; al-'Afw; al-Ishlah, al-'Adl. Dalam konflik yang terjadi dewasa ini, kaum perempuan mempunyai peranan yang signifikan dalam upaya penyelesainnya. Para aktifis perempuan Indonesia berperan dalam resolusi konflik menuju proses perdamaian sebagai Inisiator perdamaian, penyintas dan agen Perdamian.

Kata Kunci: Perdamaian, Perempuan, Konflik, Nilai alQur'an

\section{ABSTRACT}

This article examines the conflict of Qur'an perspectives about gender and the role of Indonesian women in conflict resolution efforts on a rural, regional and international scale. The results of this study indicate that conflicts in the Qur'an about gender are presented in the form of stories with conflicts. This article also examines the spirit of the Qur'an in conflict resolution, namely; tabayun (clarification), tahkim (mediation effort), al-Syura (deliberation), al-'Afw (forgiving each other), al-Islah (reconciling), al-'Adl (acting justly). The Qur'anis also 
about conflict resolution in various scattered verses. In the current conflicts, women have a significant role and efforts to resolve them. Indonesian women activists play a big role in conflict resolution that leads to the peace process as as peace initiators, survivors and an agent of peace.

Keywords: Peace, Women, Conflict, Qur'anic Value

\section{A. Introduction}

In Qur'an, Allah gives information that before humans created, there had been potential for conflict. AlBaqarah verses 30 explains that humans have potential to do a damage, evil and bloodshed. This condition shows a warning that human as creatures are full of conflict. Conflict and life are two things that cannot be separated. The existence of these two things in human life has been mentioned in Qur'an. And, scientifically, conflicts in scientific terms has now been widely discussed in order to provide direction and encouragement for the creation of goodness in human interaction

Qur'an informs people systematically that conflict already exists and becomes a provision in their lives. Humans are depicted in the Qur'an that they always fight, whether it is personal, family or social. The Qur'an describes social conflict in two kinds, namely the potential and actual conflict. Potential conflicts are mentioned in the Qur'an using the words "al-khushumah" (enmity), meanwhile the actual conflicts are described using the words "al-khilaf" (strife / quarrels) and "al-qatl" (murder).

Conflict is the relationship between two or more parties, whether it is individuals or groups who have or feel they have goals that are not in line (Fisher, 2001: 45). In other words, conflict is a process of achieving goals by weakening the opponentwithout regarding to the norms 
and values. Ifthat definition is related to the facts of life, this debilitating phenomenon has engulfed the world and even now, such problems (conflicts) are even more complex, whether it is family, neighboring, community conflicts or even cross-ethnic, religious and racial conflicts.

Conflict is a natural phenomenon. Humans will not be able to avoid conflicts within themselves. Conflict cannot be seen only as negative or destructive thing. However, conflict will make a change, depending on conflict management, whether the change is constructive or destructive. Then, the resolution of conflicts is a necessity. Conflict resolution cannot be separated from reconciliation because reconciliation is one of the stages of conflict resolution, namely the peace process. Reconciliation is a scientific terminology that emphasizes the need to see a peace as an open process and divides the process of conflict resolution in several stages in accordance with the dynamics of the conflict cycle (Said et.al, 1995: 120).

From the view point above, basically, every person, male or female, has the potential to decrease conflicts and play a role in conflict resolution. However, the effects of women's gender injustice are often seen as inferior and deemed incapable of doing positive things, including in this conflict. In particular, the women views and actions to reduce conflict are often not counted and valued. In fact, they often become targets or alternative from a conflict. When some conflicts are examined, it seems that the role of women is not so dominating. Nevertheless, in the reality, many Indonesian women activists have played a role in conflict resolution efforts in the rural, regional and even international scale.

A study on conflict resolution was ever conducted by Dahlia Lubis in a Journal entitled 'Peran Muslimah dalam Penyelesaian Konflik’ (2015). In this research, Lubis concluded 
that Muslim women have great potential to reduce conflict. Women have an urgent and very influential role in conflict resolution and even they have theological potential and opportunities supported by historical facts in order to create peace and harmony in social life. Abdul Mustaqim in his work entitled 'Konflik Teologis dan Kekerasan Agama dalam Kacamata Tafsir Al-Qur'an' (2014). In this article, Mustaqim concluded that the Qur'an recognizes several conflicts. The Qur'an also recognizes conflict as a condicio sine quo non to continue survival for the fittest. But at the same time, the Qur'an also suggests making conflict resolution. So that social harmony in multicultural societies will be achieved properly. Ira Ariesta in 'Jurnal Ilmu Sosial Mamagan 'Peran Perempuan dalam Resolusi Konflik Rehabilitasi dan Rekonstruksi Pasar Raya Padang' (2014) concluded that the gap in the role of women in the conflict resolution process of rehabilitation and reconstruction of Padang market was interpreted as the active role of women in each conflict resolution process. And, in fact, it is very small in this conflict resolution process.

The focus of this study is how the role of women in revolutionizing conflict is seen from the value of conflict resolution verses in the Qur'anic Tafsir through a hermeneutic approach (Purwanto, 2019). By examining the role of women in conflict resolution, this article focuses on the spirit of interpretation of verses constructed as norms or rules about the public role of women in conflict resolution.

\section{B. Discussion}

\section{Gender Based Conflict in Quranic Interpretation}

In the Qur'an, many events presented are nuanced in conflict, whether they are conflicts inherently in the story of the Qur'an or conflict events that becomes interpretations of the Qur'an. The following is a variety of conflicts presented 
in the interpretation of the Qur'an, but limited to conflicts that have a gender nuance. Among them are the conflicts between Qabil and Abel; Khaulah bint Tsa'labah and Aus bin Shamit; and Prophet Musa and a Qibthi.

\section{a. Qabil and Habil Conflict}

Conflict is a phenomenon that has existed since the beginning of human history. It can be referred from the Qur'an histories about the killing of Habil by Qabil, sons of Adam (Surah al-Maidah: 27-31). Even before humans were created on this earth, the Qur'an contained a dialogue between God and Angels which implied that humans would always do mischief on earth (man yufsidu fihâ) and acts of violence against each other (yasfik addima) ') (Al-Baqarah: 30). Ibn Faris (2008: 408) explains that safku al-dam means to spill blood. According to al-Syaukani (2014: 156), the context of the verse in AlBaqarah is that angels deny the adoption of humans as caliphs on earth because they have the potential to cause conflict and damage on earth. Angels said this statement before they had knowledge of humans, even before the creation of Adam. This is based on the knowledge they have learned from Allah in a certain way because they really do not know the unseen things.

In the story of Habil and Qabil, the beginning of the conflict was triggered by Qabil's dissatisfaction with the command of his father, Prophet Adam, to marry his sister Layudza. This conflict is told in the Qur'an, Al-Baqarah verses 27-31. In interpreting A-Baqarah: 27, al-Qurt\}ubi> (2014: 88) explained that this conflict wasstarted from Hawa's habit of giving birth twins (boy and girl), except when giving birth to Syits. At that time, Qabil was born with Iqlima, the beuatiful girl. Meanwhile, Habil was born with an ordinary girl 
named Layudza. When they were adults, the Prophet Adam wanted to marry Qabil with Layudza (siblings in a cross), while Habil with Iqlima. Qabil refused until there was a bloody conflict. That was a murder carried out by Qabil toHabil.

The story is gender-biased because women are used as assets. This story also gives the impression that the Prophet Adam's daughter named Iqlima has caused brotherly conflict in the history of human life. This story is considered as the basis that women from the beginning of their lives are triggers of conflict. Finally, women often get stereotypes as being difficult and always causing problems. However, there are extraordinary human values that can be taken from the story of Qabil and Habil. Adam provided a solution to resolve the conflict by making a policy of orders for sacrifice by his two children. Anyone whose sacrifice is accepted has the right to marry a more beautiful woman (Qabil's twin). Al-Ra>zi> (2012: 155) explained that the victims of the ugly corn Qabil were not engulfed in fire, while the sacrifice of the Habil goat was completely devoured. It was also mentioned that in that time, fire was a symbol of God. By being engulfed in fire, it is believed that his sacrifice was accepted by God where God is present to bless.

b. Conflict of Haulah bint Tsa'labah and her husband

The conflict between husband and wife happened at the time of the Prophet. This conflict is considered as psychological violence from a husband to his wife. The wife is Khaulah bint Tsa'labah, a shahabiyah whose confession which is immediately answered. Not just getting a solution, the problem even becomes an eternal proposition in the Qur'an. Al-Wahidi (1999: 
344) tells that Khaulah's husband, Aus bin Shamit, is an old and rude husband. One day, Aus met Khaula and yelled at him. Khaulah who could not stand then argue that it made her husband furious. Overcome by emotion, Aus said to his wife, "You're like my mother's back!" After that, Aus left his wife. Khaulah also considered her husband to have made zhihar because she considered him like his mother or mahram. This is because the Arabs used to consider zihar as talaq. Shortly thereafter, Aus went home and wanted his wife to have sex. But Khaulah avoid. She was afraid that her husband's zhihar would be counted as talaq and made Aus no longer valid as her husband. She also said to her husband, "For the sake of the Essence, my soul is in His hands. Do not close me. You have spoken what you have said, until God has decided on His law in our matter. "But Aus refused. He just jumped and wanted to reach Khaulah. But Khaulah managed to escape by pushing her husband's body. He also hurried away to meet the Messenger of Allah. In the presence of the Messenger of Allah, Khaulah confided in about the problem he was experiencing. Ayesha was there and preached the hadith about Khaulah. Ayesha said, "Indeed, a woman came who filed a lawsuit against the Messenger of Allah, while I was at the edge of the house. The woman complained about (the attitude of) her husband, and I could hear his words "Al-Wahidi (1999: 344).

The Messenger of Allah said to Khaulah, "O Khuwailah, your uncle's son is an old man, so fear you of Allah against your husband." But Khaulah was not satisfied with the Prophet's answer. He was reluctant to leave from there. After waiting for some time, Khaulah also gets an answer directly from the sky. The Prophet got word from Allah about Khaulah and her husband's 
problem. Descend Surah al-Mujadilah verses 1-4 in response to complaints and Khaulah dissatisfaction with the Prophet's answer to their problems, and explain the law of dzihar (al-Wahidi, 1999: 345).

The story above is very elevating the dignity of a woman. As portrait from the tradition of ignorance, women are not only not heard and not considered their opinions, but their presence is not even desired. The descent of QS.al-Mujadilah: 1-4 has really deconstructed the tradition. Allah's acceptance of the Khaulah suit has reversed the facts and is a new historical ink scratch on the existence and appreciation of women in the social history of Arab society (at that time) in particular and Islam in general.

\section{c. Prophet Moses and a Qibthi Conflict}

The conflict of the story of Prophet Moses and a Qibthi (native descendant of Egypt) can be found in Surah Al-Qashash. When Musa came out fromPharaoh Palace, he found a descendant of Israel and an Egyptian (Pharaoh People) quarreled, Moses accidentally helped the descendants of Israel to kill the Egyptian (Qibthi). The conflict mentioned above is illustrated in the QS. Al-Qashash: 15.

Moses already knew that the Egyptians and Israel did not live in peace and harmony, even hostile. But the question is how Moses knew that he was not really an Egyptian but from Israel. Whether his mother told him when she was breastfeeding, but it seemed that Moses would not understand anything in that age. Or Musa's mother told him later secretly when he had another chance to meet with Moses.

Or perhaps the one who frankly told it was Asiah, her foster mother, or ladies-in-waiting who knew the 
events of how the baby Moses was found. Even though Moses did not know exactly that from the Israel, simple logic could lead Asiah and ladies-in-waiting to this conclusion, because the baby was found in the year all the newborn sons of Israel would be killed by the executioner of Pharaoh.

Quraish Shihab in Tafsir Al-Mishbah (2010: 320) was more inclined to his biological mother who whispered to him that he was actually from the Children of Israel who threw his mother into the sea to avoid the cruelty of Pharaoh. Whoever told it, according to the Qur'an is that young Moses known that he was not an Egyptian but from the Israel. According to Moses, Israel men were indeed not good people, like to make a fuss. Musa immediately reproached him with words, stating that he was indeed a true heretic. However, Moses still wanted to help him because he was sure that the Egyptians were the ones who acted arbitrarily. Moses' belief, of course, was motivated by the knowledge that so far the Egyptians did indeed do wrong to Bani Israel.

Conflict told in this verse does not involve the role of women directly, but the notice both comes from the mother of the Prophet Musa and his adoptive mother Asiyah, about his schedule raises the potential of the Prophet Moses to side with the children of Israel which impacted on his involvement in the conflict between an Israeli children and a Qibti. The conflict that occurred was of course the Prophet Musa on the side of the most persecuted, but this assistance of Moses inadvertently led to the killing of a Qibti. Thus, this conflict did not involve women, but she was unintentionally involved because she told the origin of Moses who came from the Children of Israel. 


\section{Qur'anic Value On Conflict Resolution}

Conflict indeed has existed since the first humans on this earth. However, Islam as a religion of peace from an early age has also offered various solutions to prevent and avoid these conflicts. The Qur'an, in many verses has given spirit to create peace namely:

\section{a. Mediation (tahkim).}

Mediation is an effort mentioned by the Qur'an to be able to revolutionize conflicts aimed at creating peace. QS. al-Nisa ': 35 explained that if there is a conflict between husband and wife, there must be a mediator to resolve the conflict. Al-Syaukani (2014: 377) explained, mediators appointed from both parties were expected to be able to make improvements and create peace between the two. This mediation is intended as a process of resolving disputes between the two parties by bringing in a mediator or peacemaker, or each conflicting party sending mediators to negotiate their case.

The context of this verse speaks of conflicts in the household between husband and wife. Although this verse originally explains conflicts that occur between husband and wife, the spirit of conflict resolution in the verse emphasizes the importance of mediation efforts to achieve peace, whatever the conflict. Basically, all conflicts have the potential to split. So that a mediator really must position himself in the middle, not supporting one of the conflicting parties. But it could also be as stated in the paragraph above, each conflicting party sends a mediator to negotiate to resolve the problems of the two conflicting parties (Shihab, 2010: 457). 


\section{b. Clarification Efforts (taba>yun)}

Many conflicts are caused by misunderstandings or misleading information received by potentially conflicting parties. To prevent and revolutionize conflict, the Qur'an offers an effort to clarify the emergence of information that can lead to conflict. Moreover, the information that came was still unclear. So that in conflict resolution, the truth of information becomes a necessity so that accusations, conclusions or false claims regarding parties in conflict do not occur. This clarification can be done by testing the information that comes through written evidence or empirical and logical facts (Mustaqim, 2014: 168).

In QS.al-Hujurat: 6, Allah appeals to Muslims so that if there is information brought by a Fasiq (a person who makes a lot of mistakes), he must clarify it first. Indeed, the context is only to clarify information from fasiq people, the spirit is to resolve conflicts by preventing them. Today many conflicts are caused by misleading hoax information. So, how to prevent them is to clarify the information before it is distributed to others.

\section{c. Deliberation or Discussion (al-Syura).}

The Qur'an provides the spirit of deliberation to find solutions to every problem. In QS. Ali Imran: 159, it is explained that the Prophet Muhammad and the Muslims were ordered to consult in all matters. If you have tried to make a decision to determine attitudes, especially in solving problems, you are instructed to put your trust in or submit to the Essence which is in charge of all human affairs. Shihab (2002: 258) explains that deliberation comes from the word syawara, which originally meant removing honey from beehives. The 
word musyarawah is basically used in good terms. If so, those who deliberate like bees, highly disciplined creatures, amazing cooperation, the food is from flower essence, the result is honey.That is the increase from deliberation.

In the context of conflict resolution, the verse gives spirit to all people in conflict to have a discussion in deciding the best decision to find the best solution related to the conflict that is happening. Shihab (2002: 259) added that in deliberation to resolve conflicts, one must prepare mentally to be willing to forgive, because it could be that when conducting deliberations differences of opinion that offends. Thus, through deliberation is expected to get a permanent solution that can bring good to all parties. Thus, the spirit of deliberation can be used as an effort to resolve each conflict.

\section{d. Forgiving one another (al-'Afw).}

In al-Qur'an, the word al-'afw is in the QS. alBaqarah: 237. Shihab (2002: 482) explains that the context of the verse talks about a husband who has divorced his wife is not obliged to pay dowry if the wife has not been fucked. But if the husband has agreed to give the dowry, then he must give half the amount of the dowry, except if the wife forgives or frees, that is, willing sincerely not to accept it. Mutual forgiveness in the above verse gives spirit in revolutionizing conflict in every problem. If the parties in conflict with humility are able to apologize and accept forgiveness, then the problem is resolved.

e. Make peace (al-Islah).

The next conflict resolution offered by al-Qur'an is peace (al-islah). Islah is an effort to stop damage or improve the quality of something so that the benefits 
are even more. In the context of human relations, that value is reflected in the harmony of relationships. This means that if the relationship between the two parties is broken or disturbed, damage will occur and loss or at least diminish the benefits that can be obtained from these parties. This requires reconciliation, namely improvement so that harmony is restored, so that values can be fulfilled for the relationship and as a result various benefits and benefits will be born (Shihab, 2002: 596).

The word al-Islah is mentioned several times in the Qur'an with the intention of reconciling the parties to the conflict although the word al-islah contains many other meanings. First, if it comes from the word al-Sulhu, the meaning is to reconcile the two conflicting parties, contained in the QS. al-Nisa ': 35 and QS. al-Hujurat: 9. Second, if it comes from the word al-shalah, it means to do good and get rid of badness, contained in the QS. al-Anfal: 1, and QS. al-Hujurat: 10. Al-Qur'an's spirit of reconciliation is very significant to revolutionize every conflict that arises between various parties that are problematic (al-Ashfahani, 2012: 322).

\section{f. Valid Fair (al-'Adl)}

The most important thing in revolutionizing jihad is to act fairly. Without justice in giving a decision, the conflict will continue. This spirit is also mentioned by the Qur'an. In QS. al-Nisa ': 58, God commands that leaders are able to give legal judgments fairly. In interpreting this verse al-Syaukani explains when deciding on a decision, you should determine it fairly. Determination of law here based on legal sources, such as the Qur'an and Hadith combined with ijtihad (al-Syaukani, 2014: 341). This spirit of justice, when linked to conflict 
resolution, is justice that will impact on creating peace. Peaceful conditions keep people from conflict. Thus, for leaders who can lead fairly, it will be more able to create stability, security, order, peace, and kept away from conflict. This is because conflicts often occur when there is no justice in society.

\section{Implementation of the Qur'anic Values in Conflict Resolution by Muslim Women in Indonesia}

In Indonesia, women have been given the same opportunities as men in education, but people's perceptions of women have not experienced significant changes. The strong assumption is that the goal of education in women is so that they are better to be able to educate their children. Women are still considered as the second sex. Women are demeanedwhen they are only at home and exploited when they are at work. Such perceptions are not only shared by laypeople, but also intellectuals, and more concerning the government also justifies these perceptions in development policies, which are expressed in the five tasks of women: as wives and husbands' companions, educators or young generation educators, workers who add to state income and as members of community organizations, especially women's organizations and social organizations (Dzuhayatin, 1997: 34).

At this point, it is clear that discrimination against women occurs not only within the family and community, but in the concept of state even the bargaining position of women remains the second opinion not as a determinant. The role of participation in development planning is translated as a mere object and not a subject that can determine its own priorities according to the women rights and needs. Those various descriptions clearly violate the rights of women on one hand. And on the other hand showsthat this 
disgrace occurs because of misunderstanding of some men in the equalization of gender roles and functions. So that the gender bias every day is getting interesting to be shown.

Meanwhile, the involvement of women in conflict resolution and prevention is still very minimal. It can be seen from the results of UN Women research which showed that the involvement of women in the peace-building process among countries can increase the likelihood of a peace agreement being held longer than 15 years by only $35 \%$. During 1990-2017, the involvement of women as conflict mediators was only $2 \%$. While the role of women as peace negotiators is only $8 \%$. But if it has played a role in conflict resolution, women actually play an important role in various stages in the peace process, starting from conflict prevention, conflict resolution, mediation, and post conflict peace building (www.gatra.com).

On the other hand, there is a different picture from the data above that actually the role of women in revolutionizing conflict in all lines of life, whether on a rural, regional, even international scale, is not a small or minor role, but their role is quite significant unpublished and not yet widely published by the media (www.mediate.com). Unpublished efforts of women from various lines and aspects in conflict resolution tend to be detrimental because what appears to be a minor role of women and is always underestimated by those who are anti-gender discourse.

It has been explained that the role of conflict resolution of women in general is still considered less massive. Nevertheless, there are still many roles of women in resolving conflicts, whether it is in a rural, regional and even international scale. In this case, the conflict resolution carried out by these women activists tried to be harmonized with the offer of the Qur'an to resolve the problem, namely tabayun (clarification) (QS. Al-Hujurat: 6), tahkim (mediation 
efforts) (QS. an-Nisa ': 35), ash-Shura (deliberation) (Surah Ali Imran: 158), the attitude of al-'Afw (forgiving one another) (Surah al-Baqarah: 237), al-Ishlah (reconciliation) (QS) al-Baqarah: 208), al-'Adl (being fair) (Surah al-Maidah: $8)$.

a. Conflict Resolution in Village Scale

There are several studies about the role of women in reducing and revolutionizing conflict in several villages in the country. Among the conflict resolutions carried out by women activists in rural areas was a study conducted by M. Munandar Sulaeman, et al. against women in resolving conflicts among villagers, a case in Gadingan village, Sliyeg District, Indramayu Regency.

Sulaeman found that women in the village had a significant role in reducing conflicts among residents. The role of women in resolving conflicts is to be a shield and dare to take risks, and willing to sacrifice morally and psychologically for security and peace. The role of women has played a direct role in resolving conflicts magically. Resolution mechanism is done using gradual approach, cognitive response, affective, action and conflict resolution in traditional ways.

The intensity and frequency was quite high so that it could become a national issue. It was visited by the staff of the country secretary. The variables related to the occurrence of conflict were the existence of conditional prerequisite factors, namely the socio-cultural and economic aspects. While the cause of the problem was the habit of liquor as an entertainment program for art, giving rise to irritability. Likewise, factors that trigger misunderstandings in interactions lead to conflict. Because there was a cultural basis that supports brawl conflict, the event continues, especially at the time of 
the rice harvest. In that time, many celebrations were held and indirectly became an arena for conflict. Fight happened several times. It made women to take the initiative because the victims of the conflict are family and peace of life (Sulaeman et.al, 2009: 4-5).

The role of women in resolving conflict is to be a shield and dare to take risks, and willing to sacrifice morally and psychologically for security and peace. The role of women has played a direct role in resolving conflicts magically. This conflict resolution model does not exist in modern literaturebut based on local knowledge systems, it can be solved. Meanwhile, the conflict resolution mechanism played by women is passed through some steps. First isidentifying conflict problems. Second is sorting out the conflicts of the individuals involved.Third is changing the scale that will occur; but it does not work. Successful conflict solutions are carried out by substantial resistance to the element of magical power (Sulaeman et.al, 2009: 7).

From the method of women activists in Gadingan Village, it can be known that they did tabayun (clarification). In this case, activists looked for clarity and clarification of an information about the origin of the conflict. The method of resolving women's conflicts is certainly in accordance with the spirit of tabayun in the Qur' an (Q.S. al-Hujurat: 6), which also has the aim of testing the veracity of information from the parties to the conflict. Another method used by activists is mediation efforts (tahkim). In this case, the efforts of the women were carried out as a way of reconciling the two parties in conflict by bringing in mediators as peacekeepers. This is in line with Q.S. al-Nisa ': 35. In addition, the women try to reconcile (ishlah) the conflicting elements. This is in line with the Qur'anic mission of peace in QS. 
al-Baqarah: 208. Even this verse is interpreted as a verse of peace. It was explained by Ibn 'Assyur (1984: 448) that interpreted the word al-silmi in the verse in terms of al-sulh (peace), and tark al-harb (leaving the war or conflict). With the solution to leave the conflict among residents, Gadingan village community can return to live side by side in peace.

\section{b. Conflict Resolution in Regional Scale}

Conflict resolution is also often done by women on a regional scale. Among the roles and share of Indonesian women in resolving regional scale conflicts is their share in conflict resolution in Maluku. Maluku Islands sectarian conflict is an ethnic-political conflict involving religion in Maluku islands, Indonesia, especially Ambon and Halmahera Island. This conflict began in Reformation era in early 1999 until the signing of the Malino II Charter on February 13, 2002.

The main cause of this conflict was general political and economic instability in Indonesia after Suharto collapsed and the rupiah underwent devaluation during and after the economic crisis in Southeast Asia. The planned expansion of the Maluku province to Maluku and North Maluku further exacerbated existing regional political problems. Because the political problem was related to religion, a dispute broke out between Christians and Muslims in January 1999. This dispute quickly turned into fighting and acts of violence against civilians by both parties. The two main parties involved in this conflict were religious militia groups from both parties, including an Islamic group named Laskar Jihad, and Angkatan Bersenjata Republik Indonesia (ABRI) or Indonesian Army. 
The role of women in resolving conflicts in Maluku has been examined by Sri Ratna Dewi Lampong. She found that there was a significant role by women activists in efforts to resolve conflicts in Maluku. Conflicts that had occurred in Maluku since 19 January 1999 to June 2005 had brought the community to a peace process although in the stages of a conflict resolution, it was still at an early stage towards peace building. People who had been driven out began to come back to earn a fortune in the country of 'seribu pulau' or thousand islands. This conflict resolution process could not be separated from the role of women who were as the perpetrators and also the worst impact recipients of conflict. Lambong found the extent of the role of women in the process of conflict resolution in the cities of Ambon and Maluku as well as the activities undertaken to influence local governments in the process of formulating policies with a gender perspective (Lambong, 2008: 56).

According to Lambong (2008: 59), the role of women activists in the peace building process is carried out through social, economic and cultural activities. Activities carried out by women activists by gathering conflict victims to convey what was felt, followed by discussion and strengthening to live peacefully. In addition, workshops were held on the socialization of trauma healing to women, gender issues and children and the empowerment of women in all fields of life as well as empowering children and Maluku communities' victims of conflict by accompanying the two communities involved in the conflict. In addition, women activists also did control over the government in the policy making process to resolve conflicts that see the interests of all parties fairly by involving women proportionally in the decision making process. 
Based on the role of women activists in Maluku, it is understandable that they adopted the resolution method by doing Ash-Shura (deliberation). They did it to be able to solve the problem (read: find a solution) by making joint decisions. This is considered important in the case of conflict. The importance of deliberation is emphasized in Q.S. Ali Imran: 158. In addition, the women activists also took the way of the implementation of al-adl (a just solution effort). Justice is a necessity in creating conditions of peace and harmony in Maluku. Tyranny (the opposite of justice) basically will ignite conflict for those who are wronged, especially those who were in Maluku conflict. In terms of al-Qur'an, justice is referred to as diverse as al-'adl, al-qisth, and al-mizan (Surah al-Maidah: 8). This attitude of justice can deliver the Moluccans after conflict can return to peaceful life.

\section{c. Conflict Resolution in International Scale}

Conflict resolution towards the process of peace building is also sought by Indonesian women. Yenny Wahid, director of Wahid Foundation and Chairperson of Foreign Division of Muslimat NU, had carried out conflict resolution in Myanmar. Yenny visited the office of the Myanmar Embassy for Indonesia at $\mathrm{H}$ Agus Salim Street, Central Jakarta in order to convey a number of inputs to the Myanmar government regarding the resolution of the ongoing humanitarian conflict in Rakhine, Myanmar (www.wahidfoundation. org). Various treatments for violations of human rights have befallen Rohingya residents since 2012. Rohingya are an ethnic group in Myanmar who are declared not to have citizenship. Rakhine State itself is home to more than one million Rohingyas, the majority of them are Muslims. On August 25, 2017, the Myanmar military 
attacked a village in Rakhine, the majority was inhabited by Rohingyas. Myanmar troops destroyed at least 1,500 buildings and shot unarmed men, women and children. (www.wahidfoundation.org).

Especially in 2017, this humanitarian tragedy was in the spotlight of the world. The persecution to Rohingya ethnicity, Muslim citizens in Rakhine, Myanmar, became one of the most highlighted conflicts in the world in 2017. In this event, the role of Indonesian women appeared. Through diplomacy, Yenny Wahid played a role in resolving conflicts in Myanmar. In her dialogue with Myanmar's Ambassador to Indonesia, Ei Ei Khin Aye and Deputy Ambassador, Kyaw Soe Thein, Yenny Wahid expressed his hopes and suggestions to Myanmar government in order to help and resolve the humanitarian conflict in Myamar, including those affecting the Rohingya minority

In this conflict resolution, Yenny conveyed several things as a form of concern of Indonesian citizens over the events that befell the Rohingya residents. Yenny asked Myanmar military to stop their attacks on civilians immediately, including Rohingya community. She also asked the Myanmar government to protect innocent civilians. In addition to highlighting protection, Yenny also expressed her appreciation to the Myanmar government who trusted Indonesia as the only country that was given access to channel humanitarian assistance.

From Yenny Wahid's efforts, it is understood that with the power of communication such as dialogue or persuasion, women are considered capable of connecting the parties involved in the conflict. The stereotype of women who can create communication and dialogue is their gentle nature, seduction, persuasion and 
motherhood. These characteristics, if maximized, will create persuasive communication power in the role of women in reducing conflict. In addition, the strength of controlling stereotypes of other women's characteristics such as patient, compassionate and loving can be functioned and maximized as a power that has a controlling power over anger and potential conflicts that may arise.

From the conflict resolution undertaken by Yenny Wahid, it appears that she was doing tahkim (mediation efforts). In this case, the efforts of tahkim were carried out as a way to reconcile the two parties in conflict, namely Myanmar government and Rohingya citizens, by positioning them as mediators of peacekeepers. In al-Qur'an, this method is referred to in Surah alNisa': 35. As a mediator, Yenny Wahid stood in the middle, without taking sides and sympathizing with one of the parties in conflict. In addition, Yenny Wahid conducted al-Shura (deliberation), by visiting the Myanmar Ambassador in Jakarta. This effort was taken to solve the problem and find a solution by making joint decisions. This is considered important in the case of conflict in Myanmar. The assertion about the urgency of deliberation is explained in Q.S. Ali Imran: 158. The conflict resolution methods and mutual forgiveness (al-afw) as confirmed in QS. al-Baqarah: 273could be an early indicator of goodness and peace in human life in Myanmar.

\section{Conclusion}

Conflicts in the Qur'an are presented in some variants, including in the story form. Many stories in the Qur'anic interpretation with the conflict nuance gender based, namaely conflict between Habil and 
Qabil, Khaulah bint Tsa'labah and her husband, and Moses and Qibthi. The Qur'anic Value in conflict resolution, namely; tabayun (clarification), tahkim (mediation effort), ash-Shura (deliberation), al-'Afw attitude (forgiving each other), al-Ishlah (reconciling), al-'Adl (acting justly).In conflict resolution, both men and women have the same potential and role. In conflict resolution, women have a great potential to contribute in solving problems. Many women's activists in the country played a significant role in resolving the conflict towards the peace building process. The conflict resolutions that they play are sometimes on a rural, urban, regional and even international scale. The method used by women activists appears to be tabayun (clarification)., mediation efforts (tahkim) and al-Syura (deliberation). Indonesian women activists act some roles. First, as peace initiators and play a role in the process of creating peace. Second; They play a role as survivors. Third, Women acted as an agent of peace. 


\section{RREFERENCES}

al-Asfahani, Abu al-Qasim al-Husain al-Raghib (2012). alMufradat fi Gharib al-Qur'an. Kairo: Dar Ibn al-Jauzi.. Dzuhayatin, S.R.;1997, Agama dan Budaya Perempuan: Mempertanyakan Posisi perempuan dalam Islam; dalam Abdullah, I (ed); Sangkan Paran Gender; Yogyakarta: Pustaka Pelajar.

Hasan, Hasan Ibrahim, 1996, Tarikh al-Islam al-Siyasi wa alDini wa al-Saqafi wa al-Ijtima'i. Beirut: Dar al-Jail.

Hoffman, Murod,1997, .Al-Islam Kabadil. Cairo: Dar alSyuruq.

Al-Hudari, Muhammad, 1996, Al-Daulah al-Umawiyah. Cairo: al-Maktabah al-Taufiqiyyah.

Ibn 'Asyur, Muhammad Thahir, 1984, Tafsir al-Tahrir wa alTanwir. Tunis: al-Dar al-Tunisiyah li al-Nasyr).

Ibn Faris, Abu al-Husain Ahmad, 2008, Maqayis al-Lughah. Cairo: Dar al-Hadis.

Oommen, T.K, 1999, Religion as Source of Violence. Bombay: St. Martin Press.

Shihab, M. Quraish, 1999, Membumikan Al-Qur'an. Bandung, Penerbit Mizan.

2010, Tafsir al-Mishbah. Jakarta: Lentera Hati

Shihab, Alwi, 1999, Islam Inklusif. Bandung: Penerbit Mizan. Al-Syaukani, Muhammad bin Ali bin Muhammad, 2014, Fath al-Qadir al-Jami' baina Fannai ar-riwayah wa addirayah min 'ilm at-Tafsir, Beirut: Dar Ibn Hazm.

Al-Qurtubi, Abi Abdullah Muhammad ibn Ahmad, 2014, Tafsir al-Qurtubi. Beirut: Dar al-Kutub al-'Ilmiyah. 
Abdullah,Amin, 2000, "Rekontruksi Metodologi Studi Agama dalam Masyarakat Multikultural dan Multireligius" Naskah Pengukuhan Tidak Diterbitkan. tanggal 13 mei 2000.

Sulaeman, M. Munandar, et.al, 2009, "Peran Perempuan Dalam Penyelesaian Konflik Antar Warga Masyarakat Desa. (Kasus Di Desa Gadingan Kecamatan Sliyeg Kabupaten Indramayu)" Laporan Penelitian Dosen: Bandung, 2009.

Lampong, Sri Ratna Dewi, 2008, Peran perempuan dalam Resolusi Konflik: Studi tentang Konflik di Maluku, Tesis 2008, Yogyakarta: Universitas Gadjah Mada.

Mustaqim, Abdul, 2014, "Konflik Teologis Dan Kekerasan Agama Dalam Kacamata Tafsir Al-Qur'an", Jurnal Epistemé, Volume 9, Nomor 1, Juni

Lubis, Dahlia, 2015, “Peran Muslimah dalam Penyelesaian Konflik" dalam Teosofi: Jurnal Tasawuf dan Pemikiran Islam Vol. 5, No. 2, Desember.

Ariesta, Ira, 2014, "Peran Perempuan dalam Resolusi Konflik Rehabilitasi dan Rekonstruksi Pasar Raya Padang: dalam Jurnal Ilmu Sosial Mamangan, Vol. I, No. 2.

Purwanto, Tinggal, 2019, “Kesetaraan Gender Dan Relasi Kuasa Dalam Tafsir Al-Qur'an Tematik Kementerian Agama Republik Indonesia" dalam Palastren: Jurnal Studi Gender Vol. 12, No. 1, 2019.

al-Razi,Abu'AbdullahMuh\}ammad bin'UmarFakhruddin, 2012, Mafatih al-Ghaib, Kairo: Dar al-Hadis.

al-Wāhidī, Abu al-Hasan Ali bin Ahmad, 2010, Asbāb Nuzūl al-Qur'ān, Beirut: Dā al-Kutub al-‘Ilmiyyah. 
http:/ / wahidfoundation.org/index.php/news/detail/ Yenny-Wahid-Sambangi-Kedutaan-MyanmarBicarakan-Penyelesaian-Konflik-Rohingya (diakses tanggal 8 Agustus 2019 pukul 09.15 WIB).

https: / / www.gatra.com/detail/ news / 407390 Perempuan-Harus-Lebih-Dilibatkan-dalamPenyelesaian-Konflik (diakses tanggal 4 Agustus 2019, pukul 21.13 WIB).

http:// www.mediate.com/articles/birkhoff.cfm (diakses pada: 5 Oktober 2019, pukul 10.12 WIB). 